УДК 336.14

DOI https://doi.org/10.32849/2663-5313/2020.3.19

Сергій Баранов, канд. юрид. наук, дочент, професор кафедри адміністративного права та адміністративного процесу Одеського державного університету внутрішніх справ

\title{
ПРОБЛЕМНІ ПИТАННЯ ПРОЦЕСУ БЮДЖЕТНОЇ ДЕЦЕНТРАЛІЗАЦЇ̈ В УКРАЇНІ
}

У статті досліджено проблемні питання бюджетної децентралізащї як складової частини реформи дечентралізаиї влади, що нині триває в Україні. Проведено аналіз поняття бюджетної дечентралізачї, під якою пропонується розуміти прочес передачі повноважень управління доходами та видатками з метою збільшення ефективності реалізачї̈ повноважень та управління бюджетними коштами громад. З'ясовано иільову спрямованість децентралізацї - створення економічно стабільного та збалансованого розвитку України. Визначено, що головними перевагами децентралізації є насамперед створення умов для кращого забезпечення потреб місчевого населення органами місцевого самоврядування на локальному рівні. 3'ясовано роль окремих територіальних громад у процесі реалізачї бюджетної децентралізаиій. Обгрунтовано необхідність якнайшвидшого завершення проиесу їх утворення та налагодження ефективної роботи. Акиентовано увагу на питанні шодо стимулювання процесу об'єднання територіальних громад з боку держави. Розглянуто роль державної фінансової підтримки як інструменту такого стимулювання, шо полягає в наданні коштів з Державного фонду регіонального розвитку на проекти, спрямовані на підтримку добровільного об'єднання територіальних громад, надання коштів у вигляді субвениій з державного бюджету для формування відповідної інфраструктури. Проаналізовано структуру податкових надходжень до місиевих бюджетів за останні роки у зв'язку з реформою децентралізачї влади. Виявлено вплив кількісних змін бази нарахування податків, зборів та обов'язкових платежів на динаміку зміни номінальних доходів місиевих бюджетів. Встановлено, що в процесі проведення бюджетної децентралізаиї натепер є ряд проблемних питань, які виникли у ході практичного застосування нових норм бюджетного законодавства і потребують свого вирішення на законодавчому рівні. Запропоновано перелік організачійноправових заходів щодо вдосконалення процесу бюджетної децентралізації в Україні.

Ключові слова: публічне управління, децентралізація влади, місцеве самоврядування, фінансові ресурси, об'єднані територіальні громади, місцеві бюджети, податки та збори, офіційні трансферти.

Постановка проблеми. Вибраний Україною орієнтир на побудову незалежної держави з європейськими цінностями потребує удосконалення якості публічного управління у різних сферах суспільного життя, формування ефективного місцевого самоврядування на засадах децентралізації влади та нової бюджетної системи.

Бюджетна децентралізація в Україні $€$ окремою частиною загальної сукупності урядових реформ, спрямованих на підвищення ефективності діяльності сектору публічного управління. Сучасні інститути децентралізованого управління, як свідчить міжнародний досвід, забезпечують краще виконання функцій держави й ефективніше надання суспільних благ, саме бюджетна децентралізація дозволяе збалансувати механізми надання суспільних послуг з потребами та уподобаннями жителів місцевих громад.

Натепер важливим питанням для України є вдосконалення системи управління фінансовими ресурсами держави, а саме справедливий розподіл сконцентрованих у бюджеті коштів та їх ефективне використання. Розв'язання цих проблем насамперед пов'язане з реформою бюджетної децентралізації та розширенням повноважень органів місцевого самоврядування у сфері фінансів, що має наблизити кошти до споживачів.

Напрями реалізації окреслених завдань були сформульовані у прийнятих органами державної влади стратегіях та концепціях розвитку, які роблять акцент на невідкладності децентралізації бюджетних повноважень в Україні. До таких концепцій можна віднести Державну стратегію регіонального розвитку на період до 2020 року [1], Указ Президента України «Про цілі сталого розвитку України на період до 2030 року» [2] та Концепцію реформування місцевого самоврядування та територіальної організації влади в Україні [3].

Виходячи 3 наведеного, в умовах практичного здійснення реформи місцевого самоврядування постає необхідність у проведенні всебічного наукового аналізу 
отриманих iï результатів та здійснення оцінки перших здобутків від запроваджених заходів бюджетної децентралізації.

Аналіз останніх досліджень і публікацій. Проблемами розбудови місцевого самоврядування як елемента бюджетної децентралізації в Україні досліджено у значній кількості робіт вітчизняних науковців. Так, у науковій доповіді І. О. Луніної представлено результати оцінки рівня бюджетної децентралізації в Україні у 2006-2015 рр. та особливості сприйняття населенням ініціатив із децентралізації влади, проблемні аспекти розподілу повноважень у системи органів місцевого самоврядування і формування бюджетів сільських громад, визначено стратегічні завдання щодо підвищення ефективності бюджетної системи України (Lunina, 2016).

У статті I. В. Форкун та П. В. Футорного визначено сутність та види децентралізації публічних фінансів, охарактеризовано зміст фінансово-бюджетної децентралізації та визначено децентралізацію доходів i видатків, процесуальну i організаційну самостійність як основні їі складники, запропоновано функціональну залежність, за якою можна оцінювати результативність фінансово-бюджетної децентралізації, розглянуто основні європейські моделі децентралізації публічної сфери та визначено, за якою із них розвивається фінансово-бюджетна децентралізація в Україні (Forkun \& Futornii, 2016).

Перспективи використання європейського досвіду бюджетної децентралізації для України, особливості тї запровадження розглянуто в роботах Г. В. Возняк (Wozniak, 2016) та С .В. Онищенко (Onishchenko, 2016).

У наукових працях I. А. Нечаєвої проаналізовано формування та витрачання публічних фондів грошових коштів, виявлено напрями, особливості та проблеми формування та використання місцевих фінансів в Україні в умовах бюджетної децентралізації (Nechaeva, 2017).

У статті Н. П. Дребот, І. Б. Семеген проведено дослідження особливостей бюджетної децентралізації як складової частини реформи децентралізації влади, що нині триває в Україні. Виявлено ключові переваги та недоліки бюджетної децентралізації в Україні за останні чотири роки (Drebot \& Semehen, 2019).

Метою статті $\epsilon$ аналіз ситуації і визначення змін, що відбуваються у доходах місцевих бюджетів та податкових повноваженнях органів місцевого самоврядування у процесі децентралізації влади, а також обгрунтування організаційно-правових і фінансових заходів з підвищення ефективності формування податкових надходжень до місцевих бюджетів України.
Виклад основного матеріалу. Економічна ефективність вимагає проведення фінансової децентралізації, наслідком якої $\epsilon$ передача і делегування видаткових повноважень, створення фінансової бази органів місцевого і регіонального самоврядування, розробка ефективної моделі фінансового вирівнювання, залучення жителів територіальних громад до вирішення місцевих завдань.

Під поняттям бюджетної децентралізації розуміють процес передачі повноважень управління доходами та видатками 3 метою збільшення ефективності реалізації даних повноважень та ретельнішого управління бюджетними коштами громад [4, c. 56].

Бюджетна децентралізація в сучасних умовах розглядається як необхідна умова успішної децентралізації державних функцій у контексті демократичних перетворень, за допомогою якої вирішуються широке коло управлінських питань: відкриваються додаткові можливості щодо формування місцевих бюджетів; збільшується свобода у використанні коштів органами місцевого самоврядування; зростає активність й ініціатива місцевої влади; посилюється відповідальність за вирішення місцевих проблем; посилюється контроль за виконанням бюджету; підвищується результативність трансфертної політики; проводиться ефективне фінансове вирівнювання.

За умови проведення належної бюджетної децентралізації регіональні й місцеві органи влади мають можливість самостійно приймати рішення щодо фінансових питань і питань з управління територією. Слід підкреслити, що головними перевагами децентралізації є насамперед краще забезпечення потреб місцевого населення органами місцевого самоврядування на локальному рівні.

Законодавче підгрунтя для докорінної зміни системи влади та іiі територіальної основи на всіх рівнях почало формуватися в Україні ще у 2014 році. Тоді Урядом був розроблений та прийнятий основний концептуальний документ - «Концепція реформування місцевого самоврядування та територіальної організації влади» [5], на підставі якої був підготовлений «План заходів щодо їі реалізації». Ці два нормативних акти й дали старт реформі децентралізації влади в Україні [6, с. 16-19].

Верховною Радою протягом 2014-2015 років були прийняті закони про внесення змін до Бюджетного та Податкового кодексів України, що дозволило розпочати створення умов для бюджетної децентралізації, яка становить основу незалежного функціонування органів місцевого самоврядування та місцевих 
громад. Зміни до Бюджетного кодексу України (далі - БКУ) [7] стали основою для стимулювання громад до об'єднання та посилення їхньої спроможності шляхом встановлення механізму переходу об'єднаних територіальних громад на прямі міжбюджетні відносини з державним бюджетом.

Найважливішим питанням щодо стимулювання та реалізації об'єднання територіальних громад є державна фінансова підтримка, яка полягає в наданні коштів з Державного фонду регіонального розвитку на проекти, спрямовані на підтримку добровільного об'єднання територіальних громад і підготовлені відповідно до БКУ, і наданні коштів у вигляді субвенцій з державного бюджету для формування відповідної інфраструктури згідно зі стратегічними програмами розвитку територій та планами соціально-економічного розвитку (стаття 24-1 БКУ). Основним джерелом фінансування шкіл та первинної медичної допомоги є також субвенція з Державного бюджету.

Для фінансового забезпечення повноважень об'єднані територіальні громади отримають фінансові ресурси, основний з яких - 60 \% податку з доходів фізичних осіб (стаття 64 БКУ) [7].

Практика формування бюджетів місцевого самоврядування за рахунок надходжень податку на доходи фізичних осіб наявна в багатьох європейських країнах у такий спосіб місцеві громади зацікавлені у стимулюванні підприємницької актив- ності на своїй території. Крім цього основного податку, відповідно до статей 69-1, 71 БКУ, до бюджетів громад надходить: $25 \%$ екологічного податку; $5 \%$ акцизного збору з реалізації підакцизних товарів; $100 \%$ єдиного податку; $100 \%$ податку на прибуток підприємств та фінансових установ комунальної власності; 100 \% податку на майно (нерухомість, земля і транспорт), збори та інші платежі. Громади отримають фінансові ресурси, якими зможуть самостійно розпоряджатися за напрямами видатків, визначеними у статті 89 БКУ [7].

Таким чином, за останні роки в Україні була фактично запроваджена нова бюджетна модель, яка спрямована на забезпечення фінансової децентралізації, а саме збільшення обсягу фінансових ресурсів у розпорядженні органів місцевого самоврядування, формування фінансово спроможних територіальних громад.

Слід зазначити, що внаслідок проведеної податкової реформи відбулося зростання надходжень місцевих податків. Якщо у 2013 р. сума надходжень місцевих податків становила 7,3 млрд грн, то у 2017 р. - 52,6 млрд грн, за 9 місяців 2018 р. - 43,8 млрд грн. Хоча в цінах, що порівнюються, зростання на декілька порядків не спостерігається. Наявне збільшення суми номінальних надходжень місцевих податків зумовлене переведенням з 2015 р. плати за землю з категорії «збори за спеціальне використання природних ресурсів» у категорію «місцеві податки».

Доходи органів місцевого самоврядування в Україні

Таблиця 1

\begin{tabular}{|c|c|c|}
\hline Податки & Збори та інші платежі & Інші доходи \\
\hline $\begin{array}{l}\text { 60\% податків на доходи фізичних } \\
\text { осіб. } \\
\text { 80\% екологічного податку. } \\
5 \% \text { акцизного податку з реаліза- } \\
\text { ції підакцизних товарів. } \\
\text { 100\% єдиного податку. } \\
\text { 100\% податку на прибуток під- } \\
\text { приємств та фінансових установ } \\
\text { комунальної форми власності. } \\
\text { 100\% податку на майно (нерухо- } \\
\text { мість, земля, транспорт). } \\
\text { 10\% податку на прибуток підпри- } \\
\text { ємств. }\end{array}$ & $\begin{array}{l}\text { Державне мито. Плата за надання } \\
\text { адміністративних послуг. } \\
\text { Збір за місця для паркування } \\
\text { транспортних засобів. } \\
\text { Туристичний збір. Плата за } \\
\text { ліцензії та сертифікати на певні } \\
\text { види господарської діяльності. } \\
\text { Надходження від орендної плати } \\
\text { за користуванням майновим } \\
\text { комплексом та іншим майном, } \\
\text { що перебуває в комунальній } \\
\text { власності. } \\
\text { Рентні плати за користуванням } \\
\text { надрами, за спеціальне викорис- } \\
\text { тання води та водних об'єктів, } \\
\text { лісових ресурсів. } \\
75 \text { \% коштів від відшкодування } \\
\text { втрат сільськогосподарської } \\
\text { і лісогосподарської продукції. } \\
\text { Компенсаційні платежі щодо } \\
\text { об'єктів комунальної власності. } \\
\text { Інші збори та платежі. }\end{array}$ & $\begin{array}{l}\text { Різноманітні трансферти. } \\
\text { Власні надходження бюджетних } \\
\text { установ. } \\
\text { Надходження в межах програм } \\
\text { допомоги і грантів міжнародних } \\
\text { фінансових організацій та ЄС. } \\
\text { Кошти від реалізації безхазяй- } \\
\text { ного майна, знахідок, спадкового } \\
\text { майна. } \\
\text { Повернення кредитів, наданих із } \\
\text { місцевих бюджетів. } \\
\text { Кошти, отримані в процесі дер- } \\
\text { жавних закупівель. } \\
\text { Кошти пайової участі у розви- } \\
\text { тку інфраструктури населеного } \\
\text { пункту. } \\
\text { Цільові та добровільні внески. } \\
\text { Дивіденди, нараховані на акції } \\
\text { господарських товариств, у ста- } \\
\text { тутному капіталі яких є кому- } \\
\text { нальна власність. Інші доходи. }\end{array}$ \\
\hline
\end{tabular}

Джерело: складено автором на основі [7] 
Ще одним із джерел доходів місцевих бюджетів $є$ розширення кількості видів неоподаткованих надходжень та офіційних трансфертів. Щодо неподаткових надходжень, то їх зміни істотно не впливають на балансування бюджетів.

На наш погляд, не такими вже відчутними були зміни і в розділі офіційних трансфертів. Більшість місцевих бюджетів залишилися більш ніж на половину залежними від офіційних трансфертів. Частка офіційних трансфертів у доходах місцевих бюджетів починаючи з 2011 року і завершуючи 2018 роком перевищує $50 \%$. Однак слід зазначити: якщо раніше від $50 \%$ до 90 \% бюджетів різних рівнів в Україні були дотаційними, то після проведених реформ кількість дотаційних бюджетів скоротиться вдвічі [9, с. 24].
Крім позитивних зрушень, за наслідками проведення бюджетної децентралізації сьогодні існує ряд проблемних питань, які виникли у ході практичного застосування нових норм бюджетного законодавства, що потребують вирішення на законодавчому рівні. Автор підтримує думку експертів, що децентралізація бюджетного процесу (зокрема, через вилучення в обласних державних адміністрацій повноважень щодо розробки бюджетів областей, передачу окремих установ соціально-культурної сфери на фінансування з місцевих бюджетів, а також впровадження нової системи вирівнювання) у вітчизняних умовах може призвести до розбалансування всієї системи бюджетоутворення в Україні, оскільки залишається високо ймовірним закладання в місцеві бюджети заздалегідь нереальних витрат [10].

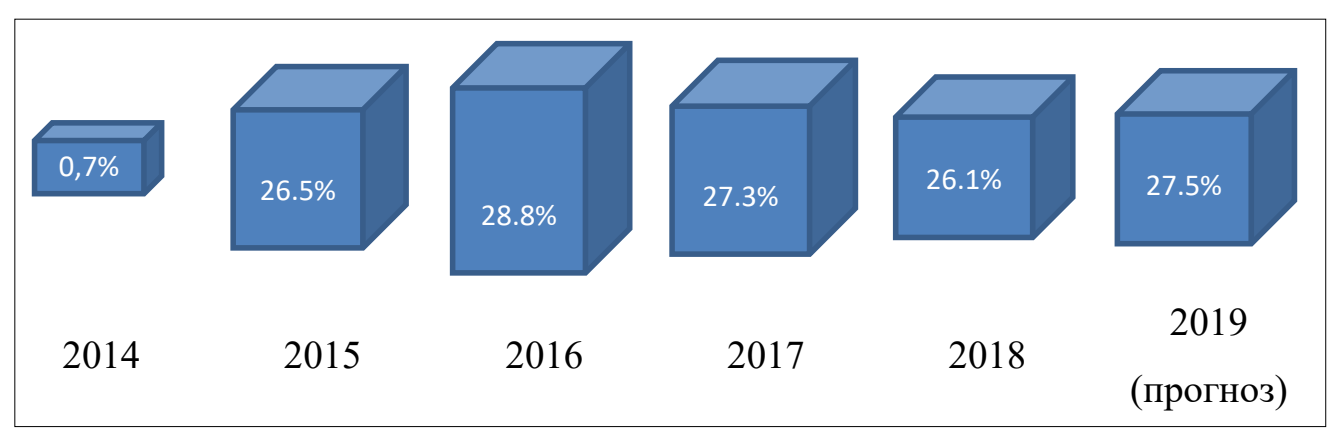

Рис. 1. Частка місцевих податків та зборів у власних доходах місцевих бюджетів (загальний фонд, у \%)

Джерело: складено автором на основі [8]

Таблиця 2

Результати бюджетної децентралізації в Україні

\begin{tabular}{|l|c|c|c|c|c|c|c|c|}
\hline \multicolumn{1}{|c|}{ Показники } & \multicolumn{7}{|c|}{ Рік } \\
\cline { 2 - 10 } & $\mathbf{2 0 1 1}$ & $\mathbf{2 0 1 2}$ & $\mathbf{2 0 1 3}$ & $\mathbf{2 0 1 4}$ & $\mathbf{2 0 1 5}$ & $\mathbf{2 0 1 6}$ & $\mathbf{2 0 1 7}$ & $\begin{array}{c}\mathbf{9} \text { міс. } \\
\mathbf{2 0 1 9}\end{array}$ \\
\hline $\begin{array}{l}\text { Доходи місцевих } \\
\text { бюджетів, млрд грн. }\end{array}$ & 182 & 225 & 221 & 232 & 294 & 366 & 502 & 414 \\
\hline $\begin{array}{l}\text { Доходи місцевих } \\
\text { бюджетів у порівняних } \\
\text { цінах 2007 р., млрд грн }\end{array}$ & 95 & 118 & 144 & 91 & 92 & 84 & 99 & 69 \\
\hline $\begin{array}{l}\text { Офіційні трансферти, } \\
\text { млрд грн }\end{array}$ & 95 & 124 & 116 & 131 & 174 & 195 & 272,6 & 226 \\
\hline $\begin{array}{l}\text { Частка офіційних } \\
\text { трансфертів у струк- } \\
\text { турі доходів місцевих } \\
\text { бюджетів, \% }\end{array}$ & 52,2 & 55,1 & 52,5 & 56,5 & 59,2 & 53,3 & 54,3 & 54,6 \\
\hline $\begin{array}{l}\text { Надходження місцевих } \\
\text { податків, млрд грн }\end{array}$ & 4,1 & 5,5 & 7,3 & 8,1 & 27,0 & 42,3 & 52,6 & 43,8 \\
\hline $\begin{array}{l}\text { Надходження місцевих } \\
\text { податків у порівняних } \\
\text { цінах 2007 р., млрд грн }\end{array}$ & 2,2 & 2,9 & 3,8 & 3,2 & 8,4 & 10,4 & 7,3 & 9,7 \\
\hline
\end{tabular}

Джерело: склав автор на основі опрачювания (Finance, 2019) 


\section{Висновки}

Виходячи 3 наведеного, можна запропонувати такі практичні кроки щодо подальшого реформування бюджетних відносин на місцевому рівні:

1. Активізація процесу децентралізації бюджетних коштів, що має стати реальним механізмом ефективного перерозподілу публічних фінансів. Реалізація даного завдання потребує не лише формальної передачі коштів на місцевий рівень, а й одночасного розширення обсягу делегованих повноважень. Це потребує чіткої структуризації та перегляду власних та делегованих повноважень органів місцевого самоврядування.

2. Вирішення питання неузгодженості моделі бюджетних відносин та адміністративно-територіального устрою. У даному контексті об'єктивно необхідним є проведення адекватної адміністративно-територіальної реформи, що дозволить визначити функціональні співвідношення між повноваженнями органів місцевого самоврядування областей, районів та місцевих державних адміністрацій. Це, своєю чергою, дозволить вирішити проблему поверховості проведення реформи міжбюджетних відносин.

3. Проведення низки організаційно-правових заходів 3 удосконалення розподілу видаткових повноважень в системі органів місцевого самоврядування.

4. Створення ефективної системи підготовки та перепідготовки кадрів для органів місцевого самоврядування. На жаль, натепер в утворених об'єднаних територіальних громадах немає необхідної кількості належно підготованих кадрів та спостерігається низька кваліфікація службовців місцевого самоврядування для виконання нових функцій. Це призводить до неефективного використання фінансових ресурсів територіальних громад, неспроможності освоїти кошти державних субвенцій на розвиток, а також сприяє корупційним проявам.

5. Враховуючи високі ризики корупційних дій щодо використання бюджетних коштів, актуальним є питання запровадження механізмів контролю за діяльністю органів місцевого самоврядування як з боку державних органів, так і з боку громадськості.

Підсумовуючи, необхідно зазначити, що, безумовно, бюджетна децентралізація
$€$ життєво необхідною умовою для становлення в Україні сучасної системи публічного управління та дійсного народовладдя. Належна реалізація іï планів дозволить державі створити економічне підгрунтя для вирішення завдань децентралізації публічної влади.

\section{Список використаних джерел:}

1. Про затвердження Державної стратегії регіонального розвитку на період до 2020 року : Постанова Кабінету Міністрів України від 06.08.2014 № 385. URL: https:// zakon2.rada.gov.ua/ laws/show/385-2014-п. (дата звернення: 11.02.2020).

2. Про цілі сталого розвитку України на період до 2030 року : Указ Президента України від 30.09.2019 № 722/2019. URL: http:// zakon3. rada.gov.ua/laws/show/9/2019. (дата звернення: 11.02.2020).

3. Про схвалення Концепції реформування місцевого самоврядування та територіальної організації влади в Україні : розпорядження Кабінету Міністрів України від 01.04.2014 № 333-p. URL: https://zakon2.rada.gov.ua/laws/show/333-2014-p. (дата звернення: 11.02.2020).

4. Василик О. Д., Павлюк К. В. Бюджетна система України. Київ : Центр навчальної літератури, 2004. $544 \mathrm{c}$.

5. Про схвалення Концепції реформування місцевого самоврядування та територіальної організації влади в Україні : розпорядження Кабінету Міністрів України від 01.04.2014 № 333-p.URL: . (дата звернення: 11.02.2020).

6. Баранов С. О. Сучасні проблеми правового регулювання процесу децентралізації влади в Україні та шляхи їх вирішення. Науковий вісник Міжнародного гуманітарного університету. Серія «Юриспрудениія» Вип. № 34. Одеса, 2018. С. 16-19.

7. Бюджетний кодекс України. URL: https: // zakon.rada.gov.ua. (дата звернення: 11.02.2020).

8. Фінансова децентралізація: експерти розповіли про результати 2018 року та перспективи 2019. URL: https: // decentralization.gov.ua/ news/10670. (дата звернення: 11.02.2020).

9. Дребот Н. П., Семеген І. Б. Реформа децентралізації в Україні: поточний стан та перспективи розвитку. Науковий вісник НЛТу Украӥни. 2019. T. 29. № 4. C. 21-24.

10. Бондарук Т. Г., Бондарук . С., Бондарук О. С. Переваги, позитивні наслідки та ризики бюджетної децентралізації. URL: https://file:/C:/ Users/ Admin/ Downloads/ nvhastat_2016_3_7. pdf. (дата звернення: 11.02.2020).

The article explores the problematic issues of budgetary decentralization as an integral part of the power decentralization reform currently under way in Ukraine. The concept of budgetary decentralization is analyzed, which proposes to understand the process of transfer of powers of management of incomes and expenditures with the purpose of increase of efficiency of realization of powers and management of budgetary funds of communities. The purpose of decentralization in order to create economically stable and balanced development of Ukraine has been clarified. It is determined that the main advantages of decentralization are first of all creation of conditions for better provision of needs of local population 
by local self-government bodies at local level. The role of individual territorial communities in the process of budget decentralization has been clarified. The necessity of completing the process of their formation and establishment of effective work as soon as possible is substantiated. Emphasis is placed on the issue of stimulating the process of integration of territorial communities on the side of the state. The role of state financial support is considered as an instrument of such stimulation, which consists in providing funds from the State Regional Development Fund for projects aimed at supporting voluntary association of territorial communities, providing funds in the form of subsidies from the state budget for the formation of appropriate infrastructure. The structure of local government tax revenues in recent years has been analyzed in connection with the decentralization reform. The influence of quantitative changes in the base of taxation, fees and compulsory payments on the dynamics of changes in nominal revenues of local budgets is revealed. It is established that in the process of budgetary decentralization, today there are a number of problematic issues that have arisen during the practical application of the new rules of the budget legislation and which need to be addressed at the legislative level. The list of organizational and legal measures to improve the implementation of the process of budgetary decentralization in Ukraine is offered.

Key words: public administration, decentralization of power, local government, financial resources, united territorial communities, local budgets, taxes and fees, official transfers. 